\title{
PENGARUH OPINI AUDIT, SOLVABILITAS DAN KEPEMILIKAN INSTITUSIONAL TERHADAP KETEPATAN WAKTU PENYAMPAIAN LAPORAN KEUANGAN (Studi Kasus pada Perusahaan Industri Dasar dan Kimia yang Terdaftar di Bursa Efek Indonesia)
}

\author{
Afifah Kurniati, Tabrani, dan Dien Noviany $R$ \\ Fakultas Ekonomi Universitas Pancasakti Tegal
}

\begin{abstract}
ABSTACT
Penelitian ini dilakukan untuk meneliti pengaruh opini audit, solvabilitas dan kepemilikan institusional baik secara parsial maupun secara simultan terhadap ketepatan waktu penyampaian laporan keuangan pada perusahaan industri dasar dan kimia yang terdaftar di Bursa Efek Indonesia selama periode tahun 2014-2016. Metode penelitian pada penelitian ini menggunakan metode kuantitatif. Teknik pengambilan sampel dalam penelitian ini menggunakan pusrposive sample dan menghasilkan 38 perusahaan. Analisis yang digunakan dalam penelitian menggunakan regresi logistik karena variabel dependen pada penelitian ini menggunakan dummy. Hasil dari penelitian ini menunjukkan bahwa opini audit dan solvabilitas secara parsial tidak mempengaruhi ketepatan waktu. Sedangkan, kepemilikan intitusional secara parsial berpengaruh tehadap ketepatan waktu. Secara Simultan, variabel opini audit, solvabilitas dan kepemilikan institusional berpengaruh terhadap ketepatan waktu penyampaian laporan keuangan.
\end{abstract}

Kata Kunci : Ketepatan waktu (timeliness), opini audit (audit opinion), solvabilitas (slovability), kepemilikan institusional (institutional ownership).

\section{A. PENDAHULUAN}

Pelaporan keuangan dan laporan keuangan merupakan hal yang berbeda. Pelaporan keuangan tidak hanya memuat laporan keuangan, akan tetapi juga mengkomunikasikan atau menyampaikan informasi keuangan sesuai dengan sistem akuntansi baik secara tersurat maupun secara tersirat. Sehingga dalam hal ini laporan keuangan merupakan media penyampaian. Pelaporan ini berkaitan dengan pihak yang berkaitan atas laporan keuangan dan standar penerapan akuntansi yang berlaku secara umum. Kewajiban perusahaan untuk menyampaikan laporan keuangan telah diatur dalam UU No. 8 Tahun 1995 Tentang Pasar Modal Pasal 86.

Dalam peraturan yang tertulis pada pasal mengenai perusahaan publik, pihak terkait mewajibkan seluruh perusahaan untuk menyampaikan laporan keuangan secara tepat waktu, yaitu selambat-lambatnya pada akhir bulan ketiga setelah tutup buku pada akhir periode pembukuan. Sanksi atas ketidak-tepatwaktuan dalam penyampaian laporan keuangan telah diatur dalam Peraturan Pemerintah Nomor 45 Tahun 1995 Tentang Penyelenggaraan Kegiatan di Bidang Pasar Modal. Pada pasal 63E mengatakan bahwa "Emiten yang Pernyataan Pendaftarannya telah 
menjadi efektif, dikenakan sansi denda Rp.1.000.000,00 (satu juta rupiah) atas setiap hari keterlambatan penyampaian laporan dimaksud dengan ketentuan bahwa jumlah keseluruhan denda paling banyak Rp.500.000.000,00 (lima ratus juta rupiah)".

Laporan keuangan yang disajikan secara berkualitas dapat meningkatkan kepercayaan publik terhadap perusahaan. Kualitas dari laporan keuangan dilihat dari karakteristik informasi akuntansi yang disajikan, seperti: relevansi, realibilitas, komparabilitas dan konsisten. Menurut Prabandari (2013), Informasi dikatakan relevan jika mengandung nilai prediksi (predictive value), nilai umpan balik (feedback value) dan ketepatan waktu (timeliness). Penundaan terhadap pelaporan keuangan yang tidak semestinya akan menyebabkan berkurangnya relevansi informasi keuangan perusahaan dihadapan publik.

Penelitian ini merupakan pengembangan dari penelitian sebelumnya yang dilakukan oleh Dewi dan Pamudji (2013). Dalam penelitian tersebut, opini audit yang wajar tanpa pengecualian (unqualified) mempunyai pengaruh yang signifikan terhadap ketepatan waktu penyampaian laporan keuangan. Selain itu, perusahaan juga mengabaikan tingkat solvabilitas Penelitian lain yang dilakukan oleh Kadir (2011) juga memberikan kontribusi dalam pengembangan penelitian ini pada variabel independen, kepemilikan manajerial dan kepemilikan isntitusional. Dari penelitian tersebut didapatkan bahwa kepemilikan pada manajerial dan kepemilikan institusional berpengaruh secara signifikan terhadap ketepatan waktu penyampaian laporan keuangan.

\section{B. KERANGKA PEMIKIRAN}

\section{Pengaruh Opini Audit terhadap Ketepatan Waktu Penyampaian Laporan Keuangan}

Opini Audit merupakan pernyataan yang dikeluarkan oleh auditor untuk menilai kewajaran atas laporan keuangan yang disajikan oleh perusahaan. Opini tersebut bagi perusahaan dapat menjadi berita baik (good news) atau berita buruk (bad news). Dikatakan sebagai berita baik (good news) karena perusahaan mendapatkan pendapat wajar tanpa pengecualian. Pendapat tersebut diberikan karena perusahaaan telah menerapkan prinsip-prinsip akuntansi yang berlaku umum di Indonesia.

Selain opini tersebut, perusahaan menganggapnya sebagai berita buruk (bad news) karena perusahaan dianggap tidak menerapkan prinsip akuntansi yang berlaku umum di Indonesia secara baik. Dari opini yang dikeluarkan oleh auditor tersebut, manajemen akan mempertimbangkan kapan waktu penyampaian laporan keuangan tersebut. Sehingga opini audit dimungkinkan dapat mempengaruhi ketepatan waktu penyampaian pada laporan keuangan.

$\mathrm{H}_{1}$ : Opini audit berpengaruh terhadap ketepatan waktu penyampaian laporan keuangan.

\section{Pengaruh Solvabilitas terhadap Ketepatan Waktu Penyampaian Laporan Keuangan}

Perusahaan mempunyai tingkat kemampuan untuk memenuhi atau membayar kewajiban-kewajiban, baik kewajiban jangka pendek maupun jangka panjangnya yang biasa disebut sebagai solvabilitas. Perusahaan dikatakan tidak solvable jika perusahaan mempunyai total hutang yang lebih besar dibandingkan dengan total asetnya.

Tingkat solvabilitas yang tinggi mengindikasikan bahwa perusahaan tidak dapat memenuhi kewajibannya untuk membayar hutang dan atau bunga kepada keditur. Dari tingkat solvabilitas 
tersebut, kreditur akan mempertimbangkan apakah mereka akan memberikan pendanaan/investasi pada perusahaan atau tidak. Sehingga solvabilitas dimungkinkan dapat memberikan pengaruh terhadapa ketepatan waktu penyampaian laporan keuangan.

$\mathrm{H}_{2}$ : Solvabilitas berpengaruh terhadap ketepatan waktu penyampaian laporan keuangan.

\section{Pengaruh Kepemilikan Institusi- onal terhadap Ketepatan Waktu Penyampaian Laporan Keuangan}

Kepemilikan saham yang dimiliki oleh pihak luar, salah satunya adalah kepemilikan institusional. Kepemilikan institusional merupakan kepemilikan atas saham perusahaan oleh suatu lembaga atau institusi. Dari kepemilikan ini, institusi memiliki kemampuan secara tidak langsung pada pengendalian perusahaan.

Kemampuan institusi tersebut dapat menekan manajemen untuk menyampaiakan laporan keuangan. Laporan yang disampaikan bukan hanya mencakup laporan keuangan mengenai kinerja keuangan perusahan, akan tetapi juga informasi lain yang berkaitan dengan perusahaan. Laporan tersebut juga merupakan bentuk tanggung jawab perusahaan kepada semua stakeholder, termasuk institusi yang menanamkan investasi di perusahaan tersebut. Sehingga institusi membutuhkan laporan tersebut untuk mempertimbangkan kelanjutan dari investasi yang ditanamkan.

$\mathrm{H}_{3}$ : Kepemilikan Institusional berpengaruh terhadap ketepatan waktu penyampaian laporan keuangan.

\section{METODE PENELITIAN}

Penelitian ini merupakan penelitian kuantitatif, yaitu penelitian yang menggunakan data kuantitatif atau kualitatif dengan hasil penelitian berupa angka.

Pengolahan data pada penelitian ini menggunakan aplikasi komputer dengan SPSS versi 17.0. penggunaan komputer ini untuk menghindari terjadinya kesalahan atau human error. Sedangkan, penggunaan uji pada penelitian ini adalah uji regresi logistik.

\section{POPULASI DAN SAMPEL}

Populasi pada penelitian ini merupakan perusahan manufaktur pada sector industri dasar dan kimia yang terdaftar di BEI selama periode 2014-2016. Sedangkan, pengambilan sampel menggunakan metde purposive sampling, dimana sampel dijaring berdasarkan kriteria dan harus memenuhi semua kriteria.

\section{E. VARIABEL PENELITIAN DAN OPERASIONAL VARIABEL}

\section{Ketepatan Waktu}

Ketepatan waktu merupakan karakteristik kualitatif pada laporan keuangan yang berhubungan dengan relevansi pada informasi yang disajikan dalam laporan keuangan tersebut (Heri, 2016).

Pada variabel ini, pengukuran menggunakan variabel dummy, yaitu dengan memberikan nilai 1 dan nilai 0 pada laporn keuangan. Laporan keuangan yang disampaikan secara tepat waktu berdasarkan peraturan merupakan laporan keuangan yang disampaikan paling akhir pada bulan ketiga setelah penutupan buku periode sebelumnya, yaitu tanggal 31 Maret. Adapun penilaiannya, sebagai berikut :

Nilai 1 : Laporan keuangan yang disampaikan oleh perusahaan secara tepat waktu.

Nilai 0 : Laporan keuangan yang disampaikan oleh perusahaan dengan tidak tepat waktu.

\section{Opini Audit}

Opini audit adalah pernyataan yang diberikan oleh seorang auditor independen atas kewajaran penyajian laporan keuangan yang telah diperiksa 
atau diaudit dalam laporan audit (Dinita, 2011).

Pengukuran pada opini audit menggunakan kategorial dengan memberikan nilai secara menurun pada opini yang diberikan. Adapun pengukurannya, sebagai berikut :

Nilai 1 : Tidak memberikan pendapat.

Nilai 2 : Pendapat tidak wajar.

Nilai 3 : Pendapat wajar dengan pengecualian.

Nilai 4 : Pendapat wajar tanpa pengecualian dengan paragraf.

Nilai 5 : Pendapat wajar tanpa pengecualian.

\section{Solvabilitas}

Solvabilitas merupakan tingkat kemampuan perusahaan untuk memenuhi atau membayar kewajiban-kewajibannya, baik kewajiban jangka pendek maupun jangka panjangnya (Hery, 2016).

Pengukuran pada variabel ini menggunakan rasio utang terhadap aset (Debt to Asset Ratio) dengan rumus :

DAR : x $100 \%$

\section{Kepemilikan Institusional}

Kepemilikan institusional adalah kepemilikan saham perusahaan oleh suatu lembaga atau institusi (Bernandhi, 2013). Kepemilikan ini dapat diukur dengan membandingkan jumlah kepemilikan saham oleh institusi dengan saham perusahaan yang beredar. Sehingga dapat dirumuskan :

\section{F. HASIL DAN PEMBAHASAN}

\section{Pengambilan Sampel}

Teknik pengambilan sampel menggunakan purpsive sampling dengan kriteria, sebagai berikut : a. Perusahaan manufaktur sektor industri dan kimia yang terdaftar di Bursa Efek Indonesia (BEI) dibawah tahun 2014.

b. Perusahaan yang menyampaikan laporan keuangan tahunan (audited) selema tiga tahun berturut-turut pada tahun 2014 - 2016.

c. Perusahaan yang pada minggu pertama dibulan kelima telah menyampaikan laporan keuangan periode 2016.

d. Perusahaan yang melampirkan laporan auditor independen dalam laporan keuangan tahunanya selama periode 2014-2016.

Dari semua kriteria, perusahaan yang memenuhi semuanya sebanyak 38 perusahaan.

\section{Statistik Deskriptif}

Tabel 4.2.2

Statistik Deskriptif

\begin{tabular}{|l|r|r|r|r|r|}
\hline & $\mathrm{N}$ & Minimum & Maximum & Mean & $\begin{array}{c}\text { Std. } \\
\text { Deviation }\end{array}$ \\
\hline K_Waktu & 114 & .00 & 1.00 & .5088 & .50213 \\
Opini_Audit & 114 & 3 & 5.00 & 4.5526 & .53368 \\
Solvabilitas & 114 & .03 & .94 & .4850 & .22068 \\
K_Institusional & 114 & .00 & .99 & .6973 & .24118 \\
Valid N (listwise) & 114 & & & & \\
\hline
\end{tabular}

Sumber : Hasil pengolahan data dengan SPSS 17.0

\section{Uji Kelayakan Model}

Uji kelayakan model regresi pada penelitian ini menggunakan Hosmer and Lemeshow's Goodness of Fit Test. Adapun hasil uji kelayakan model regresi, sebagai berikut :

Tabel 4.2.3

Hasil Uji Hosmer dan Lemeshow Test

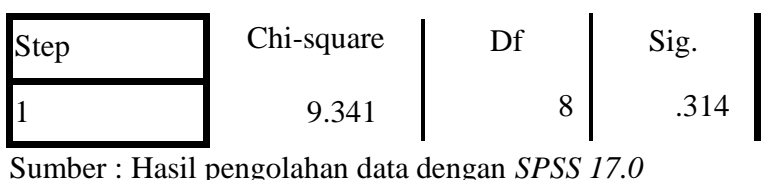


Berdasarkan tabel diatas, dapat dilihat bahwa nilai Chi-aquare pada pengujian kelayakan model regresi ini sebesar 9,341dengan nilai df 8 dan signifikansi 0,314 . Nilai signifikansi pada penelitian ini melebihi nilai alpha, yaitu 0,05. Dengan demikian, maka dapat disimpulkan bahwa data tersebut layak digunakan dalam penelitian ini dikarenakan tidak ada kesenjangan antara klasifikasi yang diprediksi dan yang diamati sehingga cocok dengan data observasinya.

\section{Menilai Keseluruhan Model (Overall Model Fit)}

Keseluruhan model pada data yang dinilai dengan membandingkan nilai -2 Log Lokelihood pada awal (Block Number $=0$ ) dan nilai -2 Log Likelihood pada akhir (Block Number $=1$ ). Nilai awal pada hasil pengolahan data ini sebesar 150,072. Setelah dimasukkan pada masing-masing variabel bebas, maka nilai -2 Log Likelihood secara konstan mengalami penurunan dan berakhir pada nilai 149,936 . Penurunan pada -2 Log Likelihood ini menunjukkan bahwa model regresi yang dihipotesiskan fit dengan data. Berikut merupakan tabel -2 Log Lokelihood pada awal (Block Number $=0)$ dan nilai -2 Log Likelihood pada akhir (Block Number $=$ $1)$ :

Tabel 4.2.4

Hasil Uji Overall Model Fita,b,c

-2Log Likelihood (Block 0 : Beginning Block)

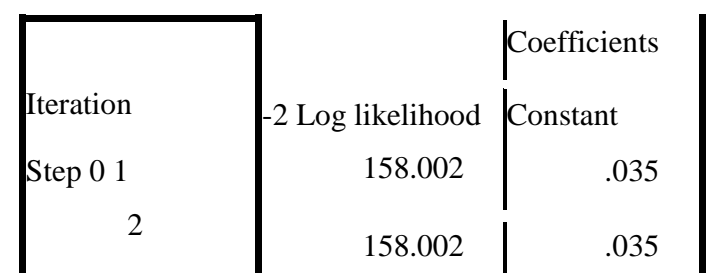

a. Constant is included in the model.

b. Initial -2 Log Likelihood: 158.002

c. Estimation terminated at iteration number 2 because parameter estimates changed by less than .001 .

Sumber : Hasil pengolahan data dengan SPSS 17.0
Tabel 4.2.5

Hasil Uji Overall Model Fit a,b,c,d

-2Log Likelihood (Block 1 : Beginning Block)

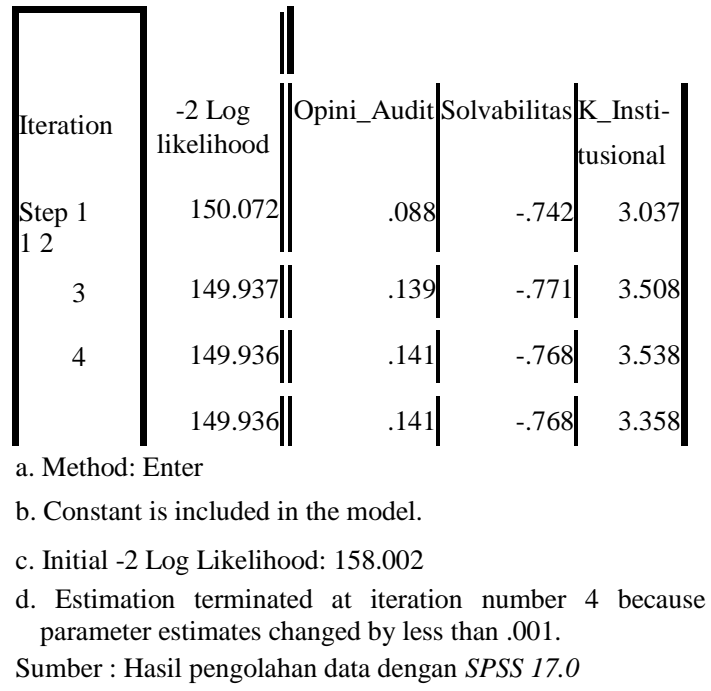

\section{Koefisien Determinasi}

Koefisien determinasi digunakan untuk menguji seberapa besar variabilitas variabel terikat dengan melihat dari nilai Nagelkerke $R$ Square. Berdasarkan pengolahan data dalam penelitian ini, nilai dari Nagelkerke $R$ Square adalah sebesar 0,091 yang berarti variabilitas variabel dependen yang dapat dijelaskan oleh variabel independen adalah sebesar $9,1 \%$, dimana sisanya sebesar $90,9 \%$ dapat dijelaskan oleh variabel-variabel lainnya di luar model penelitian in, seperti : profitabilitas, likuiditas, ukuran perusahaan, komite audit, dll. Hasil Nagelkerke $R$ Square dapat dilihat pada tabel dibawah ini :

$$
\text { Tabel 4.2.6 }
$$

Hasil Uji Koefisien Determinasi

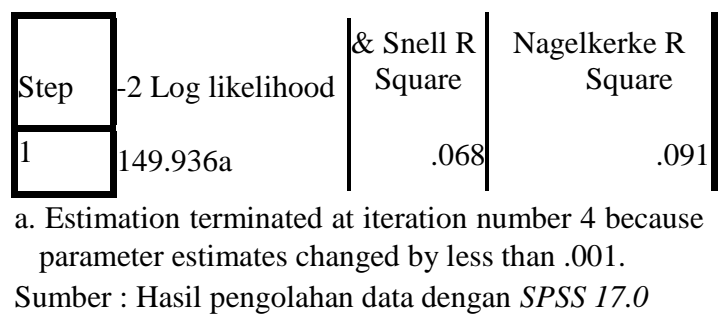

\section{Uji Regresi Logistik}

Pada nilai estimasi parameter dalam Variables in The Equation merupakan cerminan dari model regresi logistik. Pada penelitian ini estimasi 
parameter dari model regresi logsitik dan tingkat signifikasinya terdapat pada tabel di bawah ini :

Tabel 4.2.7

Hasil Uji Regresi Logistik

\begin{tabular}{|c|r|r|r|r|r|r|} 
& B & S.E. & Wald & Df & Sig. & $\operatorname{Exp}(\mathrm{B})$ \\
Step 1a Opini_Audit & .141 & 2.004 & .005 & 1 & .944 & 1.151 \\
Solvabilitas & -.768 & 1.311 & .343 & 1 & .558 & .464 \\
K_Institusion al & 3.538 & 1.433 & 6.099 & 1 & .014 & 34.392 \\
Constant & & & & & & \\
& & & & & & \\
& -1.761 & 3.521 & .250 & 1 & .617 & .172
\end{tabular}

a. Variable(s) entered on step 1: Opini_Audit, Solvabilitas, K_Institusional.

Sumber : Hasil pengolahan data dengan SPSS 17.0

Berdasarkan tabel diatas, maka model regresi logistik dapat dirumuskan, sebagai berikut :

$\operatorname{Ln}(---)=-1,761+0,141 X_{1}-0,768 X_{2}+3,538 X_{3}+e$

\section{Uji Signifikansi Parsial (Uji Wald) \\ a. Pengujian Hipotesis 1 (H1)}

Untuk menguji hipotesis pertama yang menyatakan bahwa opini audit secara parsial berpengaruh terhadap ketepatan waktu penyampaian laporan keuangan. Berdasarkan pengolahan data menggunakan SPSS 17.0 menghasilkan nilai koefisien regresi pada variabel ini sebesar 0,141 dan signifikansi yang menunjukkan nilai melebihi nilai $\alpha$ $(0,05<0,944)$ sehingga dapat disimpulkan bahwa opini audit tidak berpengaruh terhadap ketepatan waktu penyampaian laporan keuangan. Dari kesimpulan tersebut dinyatakan bahwa $\mathrm{H}_{1}$ ditolak.

Opini audit pada penelitian ini memiliki nilai yang tidak signifikan sehingga dapat diartikan bahwa opini audit tidak berpengaruh terhadap ketepatan waktu penyampaian laporan keuangan. Opini audit merupakan pendapat yang dihasilkan dari kegiatan pemeriksaan (audit) laporan keuangan perusahaan oleh auditor independen. Dalam proses audit ini, auditor diwajibkan memenuhi serangkaian kegiatan yang harus dilakukan untuk memenuhi pro- sedur audit. Meskipun auditor independen mendapat tekanan dan batasan waktu yang ditentukan dari pihak manajemen, prosedur audit tidak dapat diabaikan karena hal tersebut dapat mengurangi integritas dari auditor tersebut atau Kantor Akuntan Publik (KAP) yang menaunginya. Pihak manajemen dalam hal ini tidak dapat mencampuri proses audit untuk mempengaruhi lamanya waktu pemeriksaan dan

Selain itu, penyampaian laporan keuangan tidak hanya mengenai opini audit dari hasil pemeriksaan auditor independen. Laporan keuangan tahunan yang disampaikan pada Otoritas Jasa Keuangan (OJK) telah diatur dalam Peraturan Ototitas Jasa Keuangan (POJK) Nomor 29/POJK.04/2016 Pasal 4. Laporan yang disampaikan wajib disampaikan paling sedikit memuat, ikhtisar data keuangan yang penting; informasi saham; laporan direksi; laporan dewan komisaris; profil emiten; analisis dan pembahasan manajemen; tata kelola emiten; tanggung jawab sosial dan lingkungan emiten; serta surat pernyataan anggota direksi dan anggota dewan komisaris mengenai tanggung jawab laporan tahunan. Penelitian ini juga sependapat dengan penelitian yang dilakukan oleh Prabandari (2013) yang menyatakan bahwa opini audit tidak berpengaruh terhadap ketepatan waktu penyampaian laporan keuangan.

\section{b. Pengujian Hipotesis $2\left(\mathrm{H}_{2}\right)$}

Hipotesis kedua menyatakan bahwa solvabilitas secara parsial berpengaruh terhadap ketepatan waktu penyampaian laporan keuangan. Dengan koefisien regresi pada variabel ini memiliki nilai sebesar 0,768 pada posisi negatif dan tingkat signifikansi pada variabel ini sebesar 0,558 dimana nilai tersebut melebihi nilai $\alpha$, yaitu 0,05 , sehingga dapat disimpulkan bahwa solvabilitas tidak berpengaruh terhadap ketepatan waktu penyampaian laporan keuangan. Dengan demikian disimpulkan bahwa $\mathrm{H}_{2}$ ditolak.

Solvabilitas merupakan tingkat kemampuan perusahaan untuk membayar kewajiban-kewajibannya. Berdasarkan hasil dari pengolahan data, 
solvabilitas tidak mempengaruhi ketepatan waktu penyampaian laporan keuangan. Tingkat solvabilitas tidak akan mempengaruhi ketepatan waktu penyampaian laporan keuangan. Hal tersebut dikarenakan ketepatan waktu merupakan kewajiban yang telah diatur oleh peraturan yang baku, baik perutaran perundang-undangan maupun lembaga pengawas, dalam hal ini OJK. Manajemen cenderung memilih menyampaikan laporan keuangan secara tepat waktu tanpa memperhatian tingkat solvabilitas karena hal tersebut dapat menghindarkan perusahaan dari pandangan negatif pengguna laporan keuangan mengenai kinerja dan integritas perusahaan. Hasil dari penelitian ini sama dengan penelitian yang dilakukan oleh Dewi dan Pamudji (2013). Pada penelitian tersebut, solvabilitas tidak berpengaruh terhadap ketepatan waktu penyampaian lapran keuangan.

\section{c. Pengujian Hipotesis $3\left(\mathrm{H}_{3}\right)$}

Hipotesis yang terkahir menyatakan bahwa kepemilikan institusional secara parsial berpengaruh terhadap ketepatan waktu penyampaian laporan keuangan. Berdasarkan pengolahan data pada tabel 4.2.8 menunjukkan bahwa koefisien regresi bernilai 3,538 pada posisi postitf dengna nilai signifikansi yang melebihi nilai $\alpha(0,05<0,014)$ sehingga dapat diartikan bahwa kepemilikan institusional yang meningkat berpengaruh secara terhadap ketepatan waktu penyampaian laporan keuangan, dimana semakin banyak saham yang dimiliki oleh lembaga atau institusi maka perusahaan cenderung akan menyampaikan laporan keuangan secara tepat waktu. Dari hasil tersebut disimpulkan bahwa $\mathrm{H}_{3}$ diterima.

Hasil penelitian menunjukkan bahwa kepemilikan institusional secara parsial berpengaruh terhadap ketepatan waktu penyampaian laporan keuangan. Hal ini ditunjukkan dengan nilai signifikansi yang kurang dari nilai $\alpha$ dengan arah koefisien regresi positif. Kepemilikan institusional memiliki pengaruh terhadap ketepatan waktu penyampaian laporan keuangan.
Variabel ini mempunyai pengaruh yang positif dimana kepemilikan institusional yang semakin banyak akan meningkatkan kemungkinan perusahaan untuk menyampaikan laporan keuangan secar tepat. Hal tersebut dapat dikarenakan lembaga atau institusi memiliki sumber dana yang dominan atau menampung dana dari masyarakat lain, hal tersebut dapat memberikan kekuatan bagi suatu institusi untuk menekan manajemen dalam menyampaikan laporan keuangan secara tepat waktu. Penelitian ini serupa dengan penelitian Kadir (2010) yang menyatakan bahwa kepemilikan institusional secara parsial berpengaruh terhadap ketepatan waktu penyampaian laporan keuangan.

\section{Uji Simultan (Omnibus Test of Model Coefficient)}

Uji simultan pada regresi logistik menggunakan tabel Omnibus Test of Model Coefficient dimana uji tersebut dilakukan untuk mengetahui pengaruh variabel independen secara simultan atau bersama-sama berpengaruh terhadap ketepatan waktu penyampaian laporan keuangan. Variabel independen secara simultan berpengaruh apabila hasil dari pengolahan data pada pengujian ini menunjukkan bahwa salah satu variabel independen mempunyai nilai signifikansi kurang dari nilai $\alpha$. Adapun hasil dari pengolahan data pada pengujian ini, sebagai berikut :

Tabel 4.2.8

Hasil Uji Omnibus Tests of Model Coefficients

\begin{tabular}{|l|r|r|r|} 
& Shi-square & Df & Sig. \\
Step 1 Step & 8.066 & 3 & .045 \\
Block & 8.066 & 3 & .045 \\
Model & 8.066 & 3 & .045 \\
\hline Sumber : Hasil pengolahan data SPSS 17.0
\end{tabular}

Berdasarkan tabel diatas, nilai signifikansi sebesar 0,045 dimana nilai tersebut tidak lebih dari nilai $\alpha$, yaitu 0,05 . Dengan hasil yang demikian, maka dapat disimpulkan bahwa variabel independen yang meliputi, opini audit, dan solvabilitas 
dan kepemilkan institusional secara simultan berpengaruh terhadap ketepatan waktu penyampaian laporan keuangan dengan tingkat kepercayaan 95\%..

\section{G. KESIMPULAN DAN SARAN}

\section{Kesimpulan}

Hasil penelitian dari perusahaan industri dasar dan kimia selama periode 2014-2016 menghasilkan kesimpulan, sebagai berikut :

a. Opini audit tidak berpengaruh terhadap ketepatan waktu penyampaian laporan keuangan dengan nilai signifikasi sebesar 0,994. Hal tersebut disebabkan karena lamanya waktu proses audit tidak dapat dipastikan. Selain itu, laporan yang disampaikan kepada Otoritas Jasa Keuangan tidak hanya memuat lapran audit. Ada beberapa laporan lainnya yang harus disampaikan, seperti: csr, dewan direksi, dan laporan lainnya, yang belum memadai setelah penerimaan laporan audit.

b. Nilai signifikansi pada solvabilitas sebesar 0,558 sehingga solvabilitas tidak berpengaruh terhadap ketepatan waktu penyampaian laporan keuangan. Manajemen cenderung ingin menyampaikan laporan keuangan secara tepat waktu tanpa memperhatikan tingkat solvabilitas untk menjaga integritas perusahaan di mata publik.

c. Kepemilikan institusional berpengaruh terhadap ketepatan waktu penyampaian laporan keuangan, hal tersebut ditunjukkan dengan nilai signifikansi yang melebihi nilai $\alpha$, yaitu sebesar 0,041. Lembaga atau institusi mempunyai kekuatan untuk menekan manajemen dalam menyampaikan laporan keuangan. Semakin tinggi kepemilikan institusional, semakin tinggi pula tingkat ketepatan waktu penyampaian laporan keuangan.

d. Semua variabel independen (opini audit, solvabilitas dan kepemilikan institusional) pada penelitian ini berpengaruh terhadap ketepatan waktu penyampaian laporan keuangan dengan tingkat kepercayaan sebesar $95 \%$.

\section{Saran}

Berdasarkan hasil penelitian, maka saran yang dapat disampaikan oleh peneliti, sebagai berikut :

a. Bagi akademisi disarankan dalam penelitian selanjutnya, peneliti menyarankan untuk menambahkan rentang waktu penelitian sehingga hasil penelitian lebih akurat. Selain itu, penelitian selanjutnya dapat menambahkan variabel-variabel lainnya, seperti: ukuran perusahaan, komite audit, profitabilitas, solvabilitas dan lainnya yang diperkiraan mempengaruhi ketepatan waktu. Selain itu, akademisi dapat menggunakan penelitian ini dengan baik sebagai bahan acuan atau penambah wawasan.

b. Bagi investor disarankan untuk membaca penelitian ini sebagai bahan tambahan untuk mempertimbangkan keputusan dalam berinvestasi. Dengan melihat pada ketepatan waktu penyampaian laporan keuangan investor dapat memperkirakan relevansi dari laporan keuangan itu sendiri.

c. Bagi reviewer disarankan untuk mengoreksi penelitian ini dan memberikan tambahan-tambahan jika diperlukan. 


\section{DAFTAR PUSTAKA}

Andayani, Wuryang. 2008. Audit Internal. Yogyakarta : BPFE

Ardianingsih, Arum dan Komala Ardiyani. 2012. “Analisa Pengaruh Struktur

Kepemilikan terhadap Kinerja Perusahaan” dalam Jurnal Ilmiah. Hal : 97.

Baridwan, Zaki. 2013. Intermediate Accounting. Yogyakarta : BPFE Belkaoui, A. Riahi. 2006. Teori Akuntansi. Jakarta : Salemba Empat

Bernandhi, Riza. 2013. "Pengaruh Kepemilikan Manajerial, Kepemilikan Institusional, Kebijakan Dividen, Leverage dan Ukuran Perusahaan terhadap Nilai Perusahaan" dalam Skripsi. Hal : 14.

Boynton, William C, Raymond N. Johnson dan Walter G Kell. 2003. Modern Auditing.

Jakarta : Erlangga

CNN. 2016. "Telat Sampaikan Laporan Keuangan, BEI Suspensi Saham 18

Perusahaan" dalam CNN Indonesia. Jakarta. 10 Januari 2017.

Dewi, Karina M dan Sugeng Pamudji. 2013. “Analisis Faktor-faktor yang Mempengaruhi Ketepatan Waktu dan Audit Delay Penyampaian Laporan Keuangan" dalam Jurnal Ilmiah.

Dinita, Iffani. 2011. "Pengaruh Opini Audit dan Audit Report Lag terhadap Ketepatan Waktu Penyampaian Laporan Keuangan dengan Reputasi KAP sebagai variabel Moderating pada Perusahaan Manufaktur di Bursa Efek Indonesia" dalam Skripsi. 17 Januari 2017. Hal : 40.

Ghozali, Imam. 2011. Aplikasi Analisis Multivariate dengan Program IBM SPSS19.

Semarang : BP Universitas Diponegoro

Halim, Abdul. 2015. Auditing 1 : Dasar-dasar Audit Laporan Keuangan. Yogyakarta : UPP STIM YKPN.

Hanafi, Mamduh M dan Abdul Halim. 2016. Analisis Laporan Keuangan. Yogyakarta : UPP STIM YKPN

Hery. 2016. Analisis Laporan Keuangan. Jakarta : Grasindo

Hilaliya, Lukita Nur. 2016. "Pengaruh Ukuran Perusahan, Profitbilitas, Tingkat Pertumbuhan dan Biaya Hutang terhadap Leverage pada Perusahaan Property dan Real Estate yang Terdaftar di BEI Tahun 2010-2014” dalam Skripsi.

Islam, Lathiefatunnisa Nur. 2015. "Faktor-faktor yang Mempengaruhi Ketepatan Waktu Pelaporan Keuangan Perusahaan : Profitabilitas sebagai Variabel Moderating" dalam Skripsi. Hal : 20-21.

Jusuf, Amir Abadi (Ed). 2003. Auditing : Pendekatan Terpadu. Jakarta : Salemba Empat.

Kadir, Abdul. 2011. "Faktor-faktor yang Mempengaruhi terhadap Ketepatan Waktu Pelaporan Keuangan” dalam Jurnal Vol. 12 No. 01. 
Kurnawati, Astrid. 2014. "Faktor-faktor Ketepatan Waktu Penyampaian Laporan Keuangan pada Perusahaan Manufaktur yang Go Pubik di Indonesia" dalam Jurnal Ilmiah.

Mareta, Sigit. 2015. "Analisi Faktor-faktor yang Memengaruhi Timeliness Publikasi Laporan Keuangan” dalam Jurnal Ilmiah. Vol. XIX, No. 01 Januari 2015. Hal: 93108

Mulyadi. 2002. Auditing. Jakarta : Salemba Empat

Munawir, S. 2010. Analisa Laporan Keuangan. Yogyakarta : Liberty Niswonger, C. Rollin, dkk. 1999. Prinsip-prinsip Akuntansi. Jakarta : Erlangga Prabandari, Pramesty. 2013. "Analisis Faktor-faktor yang Mempengaruhi Ketepatan Waktu Penyampain Laporan Keuangan pada Perusahaan Pertambangan yang Terdaftar di Bursa Efek Indonesia” dalam Jurnal Profita. Hal : 22

Pujiati. 2015. "Pengaruh Kepemilikan Manajerial, Kepemilikan Institusional, dan Kesempatan Investasi terhadap Kebijakan Dividen dengan Likuiditas sebagai Variabel Pemoderasi” dalam Skripsi.

Putra, I Gede A.P, dan I Wayan Ramantha. 2015. "Pengaruh Profitabilitas, Umur Perusahaan, Kepemilikan Institusional, Komisaris Independen, dan Komite Audit pad Ketepatwaktuan Publikasi Laporan Keuangan” dalam Jurnal Vol. 10 No. 1.

Rianti, Rensi. 2014. "Pengaruh Profitabilitas, Leverage, Kepemilikan Institusional dan Kepemilikan Mnajerial terhadap Ketepatan Waktu Pelaporan Keuangan" dalam Skripsi.

Sabrina, Anindhita Ira. 2010. "Pengaruh Corporate Governance dan Struktur Kepemilikan terhadap Kinerja Perusahaan" dalam Skripsi.

Soemarso. 2013. Akuntansi : Suatu Pengantar. Jakarta : Salemba Empat.

Solikhah, Annida Unsa. 2015. “ Pengaruh Ukuran Direksi, Komite Audit, Kepemilikan Manajerial dan Kepemilikan Institusional terhadap Kinerja Keuangan” dalam Skripsi.

Sugiyono. 2013. Metode Penelitian : Kuantitatif dan Kualitatif R\&D. Bandung : Alfabeta

Sugiyono. 2014. Statistik Penelitian. Bandung : Alfabeta

Sukarman, Syahresy. 2015. "Analisis Faktor-faktor yang Mempengaruhi Ketepatan Waktu Penyampaian Laporan Keuangan Emiten di Pasar Modal” Skripsi.

Suwardjono. 2014. Akuntansi Pengantar 1: Proses Penciptaan data Pendekatan Sistem. Yogyakarta : BPFE

Tandiontong, Mathius. 2015. Kualitas Audit dan Pengukurannya. Bandung : Alfabeta

Toding, Merlina dan Made G Wirakusuma. 2013. "Faktor-faktor yang Memengaruhi Ketepatawaktuan Penyampaian Laporan Keuangan” dalam Jurnal Ilmiah

Ulum, Ihyaul. 2012. Auditing Sektor Publik : Suatu Pengantar. Jakarta : Bumi Aksara

Weygant, Jerry J., Donald E Kieso, dan Paul D Kimmel. 2007. Pengantar Akuntansi 1. Jakarta : Salemba Empat. 
Widiana, Dina. 2012. "Analisis Pengaruh Struktur Kepemilikan dan Jenis Industri terhadap Tingkat Pengungkapan Tanggung Jawab Ssial Perusahaan" dalam Skripsi.

Wijayanti, Ngestiana. 2009. "Pengaruh Profitabilitas, Umur Perusahaan, Ukuran Perusahaan dan Kepemilikan Publik terhadap Ketepatan Waktu Pelaporan Keuangan Perusahaan” dalam Skripsi.

Yusralaini, Restu Agusti dan Livia Dara Raesya “Analisis Faktor-faktor yang Mempengaruhi Ketepatan Waktu Penyampaian Laporan Keuangan ke Publik pada Perusahaan yang Terdaftar di BEI 2005-2007”. Vol. 18 No. 2 Juni 2010.

Yftiyana, Tya. 2013. "Pengaruh Leverage, Struktur Kepemilikan dan Ukuran Perusahaan terhadap Luas Pengungkapan Laporan Keuangan pada Perusahaan Perbankan yang Terdaftar di Bursa Efek Indonesia" dalam Skripsi. 